\title{
Tax Compliance and Digitalization of Nigerian Economy: The Empirical Review
}

\author{
Raphael Sunday Etim, PhD \\ Department of Accounting \\ University pf Uyo, Uyo \\ Akwalbom State \\ Mfon Solomon Jeremiah, $P h D$ \\ Department of Accounting \\ University of Uyo, Uyo \\ Akwalbom State \\ Patrick B. S. Dan \\ Department of Accounting \\ Federal University of Birnin, Kebbi \\ Kebbi State
}

\begin{abstract}
The paper examined the effect of digitalization of economy on tax compliance in Nigeria. The researcher adopted the survey strategy and use structured questionnaire to collect data. The data was sourced from the Federal Inland Revenue Service (FIRS)in AkwaIbom State. The data was collected from the entire population of the staff at the FIRS, which was forty (40). The simple percentage, descriptive statistics, and linear regression techniques were used to analyze the data. The results suggest that tax compliance is negatively influenced when economy is digitalised. It is therefore recommended that the government of Nigeria should consider developing tax policy that would aid taxing e-transactions, tax education and including taxation of e-transactions in the tax laws. Doing so would likely improve tax compliance and thus boost digital transactions contribution to government revenue.
\end{abstract}

Key words: Taxation, digitalized economy, e-transactions, tax compliance in Nigeria

\section{Introduction}

Digitalisation is transforming many aspects of our everyday lives and the way our economy and society functions. The change brought about by this digital transforming is notable and it raises public policy challenges (Adewoye and Olaoye,2014).It is also changing the nature of policy-making itself, through the emerging of new range of tools required to support the development and implementation of policies. Ubiquitous digital devices, connectively and smart technology are bringing significant changes that are profoundly affecting relationship and market.

Information and communication technology (ICT) have become part of the foundational infrastructure of business and society (Ibrahim, Jeremiah and Ithnin, 2008)); the evidence is the heavy reliance on efficient and widely accessible online communication network and services, data, software and hardware (Adigboleand Olaoye,2013). Enormous data is now generated by these constantly connected users and devices. These data being collected by businesses and government and combined with advanced data analytics and technology diffusion, are providing the insights necessary to transform and shape the way organisations operate.In this changing environment, the challenges for policymaker are complex. For tax matters, this means that policy development and implementation must be designed to allow for the changing environment. The policy should be clear to provide the certainty that would facilitate sustainable long-term economic growth.

Indeed, digital economy is becoming the world most innovative and far reaching economy. In 2018, the Nigerian investment promotion commission projected that the Nigeria's digital economy would generate \$88billion dollar and create three million new jobs by the end of 2021. However, Nigeria may be unable to tax the huge income that the digital economy would generate unless it amends it laws to adapt to changing technological advancement(Adewoye, Ademola, Afolabi and Oyeleye, 2013).

Typically, the general rule under Nigeria tax laws for taxing income of foreign enterprises in a given jurisdiction is by establishing that the entity has a taxable presence or as permanent establishment (PE) in Nigeria. Given that digital transactions require little or no physical presence of the transacting parties, the income from the transaction may not be captured in the jurisdiction where the income is derived. Whilst, the Nigerian tax authorities are working towards ensuring digitalization of the tax collection process, it is unfortunate that this digitalization has not been extended to cover effective monitoring and collection of taxes from digital transactions. It is for these reasons that the study was conducted to ascertain the effect of digitalization of the economy on tax compliance in Nigeria. 


\section{Literature Review}

The review of related literature was carried out under three sub- headings namely conceptual review, theoretical review and empirical review.

\subsection{Conceptual Review}

\subsection{Taxation and its nature}

Tax is a compulsory payment made by individuals and organisations to the government in accordance with predetermined criteria for which no direct or specific benefit is received by the taxpayer.(Bassey, 2016). The following are the features of tax: it is compulsory payment usually backed up by law, it is levied according to predetermined criteria, paid to government and not individual and it is for the common benefit of the citizens. It is obvious that countries, including Nigeria, impose taxes for a number of reasons. Government uses tax revenue as a means of financing government activities, reducing consumption of goods considered non- essential, reducing inequality in income distribution, ensuring price stability and helping to stimulate economic growth.In his book, the wealth of Nations, Adam Smith laid down the basic cannons that should be observed by nations in fashioning out tax policies; these include equity, certainty, convenience and economy.

\subsubsection{Digital Economy and Benefits}

Digital Economy is defined as the part of economic output derived solely or primarily from digital technologies with a business model based on digital goods or services (Adimassuand Jerene, 2015). The digital economy is made up of various components, including a platform economy, data analytics, robotics and Artificial Intelligence (AI), machine learning, 3-D printing, and e-commerce among others (Ernst and Young, 2018).For countries in Africa, the digital economy offers opportunities, but also brings risks of being left behind. Improved digital connectivity can only achieve the desired transformational impact on economic opportunity and inclusive growth if combined with improvements in digital skills and literacy, the coverage of digital identity schemes, and access to digital payments and other financial services, as well as digital support to start-ups and existing businesses. With such capabilities, the African economy can harness digital data and new technologies, generate new content, link individuals with markets and government services, and roll out new and sustainable business models.

In most of the Africa countries today, too few citizens have digital IDs or transaction accounts-locking them out of access to critical public services, financial inclusion, and markets. Digital start-ups struggle to attract funding, and 'traditional' businesses are only slowly adopting digital technologies and platforms to boost productivity and sales (Amabali, 2009). There is a shortage of workers with the digital skills needed, and limited digital literacy holds back adoption and use of digital products and services. Inadequate policy and regulatory frameworks, including for data protection, cyber security, and competition, also constrain the development of a digital economy in Africa.Digital economies also introduce new risks-to consumers, creditors, or firms, on personal data and cyber threads, in ways systemic or otherwise, and would require safeguards to mitigate these risks and ensure robust job markets (Akintoye and Tashie, 2013). A key area of concern has been that widespread adoption of automation and other digital technologies can cause significant net job losses. However, in the aggregate, technological change has not led to a significant increase in joblessness, and global employment continues to expand in line with the growth in the labour force (ILO, 2018). Though it may displace jobs, automation using technology causes creative destruction, stripping some jobs while creating new ones.

Additionally, while digital economic development can be critical, the process is neither linear nor a panacea. Effective prioritization and sequencing are required, especially as they deal with the public sector. For example, if public service delivery is a key priority to improve the targeting of the poor, the development of government platforms will need to be prioritized. Key investments and reforms may also need to be prioritized as part of an overall development strategy. Shifting cash into digital accounts for government payments, remittances, Small and Medium Enterprise (SME) payments, and agricultural value-chain payments can enable broad-based participation in the digital economy (Amabali,2009). Digital financial services can be more accessible for lower-income segments of the population, and for women and agricultural households-population segments often underserved by traditional financial services.

A digital economy has potential to enhance productivity and gains in multiple ways. A digital economy can change the way economies of scale are achieved, particularly with online service delivery, as the incremental cost of offering an additional product or service may become negligible (Dzidonu,2012). The digital economy may provide better matching of buyers and sellers in a competitive marketplace. It may address certain concerns with asymmetric information, solving some principal-agent problems where buyers and sellers are separated by intermediaries, or even multiple levels of intermediaries (Batrancea,Nichita and Batrancea, 2012). It may strengthen people's trust in firms or governments by enabling some decentralized forms of trust where centralized authorities are not trusted. It may allow products and services to be customized and targeted-enabling better inclusion but also easier ways to exclude some too. 


\subsubsection{Electronic Tools for Managing Taxes in Digitalized Economy}

Electronic tools for managing taxes are devices and resources used to communicate, create, manage, and share information. They include hardware (computers, modems, and mobile phones), software (computer programs, mobile phone applications), networks (wireless communications, Internet) and they are basically concerned with the purpose of collecting, processing, storing and transmitting relevant information to support the management operations in any organizations (Adewoye and Olaoye, 2014). It is a system that provides historical information on current status and projected information, all appropriately summarized for those having an institutions or firms (Adigbole and Olaoye, 2013). Obi (2003) conceptualized that electronic system is useful in the area of decision making as it can monitor by itself disturbances in a system, determine a course of action and take action to get the system in control. Adewoye and Olaoye (2014) stated that the future planning of electronic system is built using the following: people, data processing, data communication, information system and retrieval and system planning.

\subsubsection{Tax Compliance in Nigeria}

Tax compliance is perceived to be behavioural induced toward government actions on provision of basic infrastructural amenities. However, Batrancea, Nichita and , Batrancea (2012) identified social psychological issues, political, industry, business and economic among others as the determinant of tax compliance behaviour. Efunboade (2014) stated that introduction of tax week, filing tax returns, tax counselling, establishing tax electronic management system, regular auditing and examination, penalty provisions, tax education are capable of improving the satisfactory level of revenue in developing countries through self-assessment. While, Okello, (2014) identified education, provision of service- oriented attitude, enacting stringent deterrents to non-compliance, regular auditing and transparency on the part of government and tax authority will enhance voluntary compliance capable of improving revenue generation.

The plan of action to achieve compliance with tax laws without cohesion and enforcement is vital in improving the revenue of tax authority (Appah and Ogbonna, 2014). Strategically meeting taxpayers' needs through the provision of essential amenities, transparency and accountability and among others can induce voluntary compliance. Akintoye and Tashie (2013) conclude that the provision of infrastructural amenities, moral ethics, tax rate, tax accountability and confidence in government, the level of service delivery and the efficient system of tax payment in Lagos state Nigeria motivated the voluntary compliance to pay tax by taxpayers. Voluntary non-compliance has necessitated the compliance gaps in tax revenue of most states in Nigeria. Adimassu and Jerene (2015) identified economic, demographic, social, institutional, individual factors as the determinant of voluntary tax compliance behaviour in self-assessment system in Ethiopia. Appah and Ogbonna (2014) stated that revenue generation in Nigeria is significantly affected by self-assessment compliance. Thus, an efficient compliance strategy increases revenue generation positively.

\subsubsection{Digitalization and Tax Systems in the World}

Digitalization has a wide range of implications for taxation, impacting tax policy and tax administration at both the domestic and international level, offering new tools and introducing new challenges. As a result, the tax policy implications of digitalization have been at the centre of the recent global debate over whether or not the international tax rules continue to be fit for purpose in an increasingly changing environment. Before the release of Base Erosion and Profit Shifting (BEPS), political leaders, the media, and civil society around the world have expressed growing concerned about tax planning by multinational enterprises (MNEs) that take advantage of gaps in the interaction of different tax systems to artificially reduce taxable income or shift profit to low-tax jurisdiction in which little or no economic activity is performed. BEPS was structured around the following three (3) key pillars:Improving coherence in the domestic rules that affect cross-border activities; reinforcing substance requirements to ensure alignment of taxation with the location of economic activity and value creation and enhancing transparency and certainty for businesses and government.

\subsubsection{Addressing the Tax Challenges of the Digital Economy Worldwide}

The 2015 BEPS action one report, addressing the tax challenges of the digital economy, which was release in October, 2015 did recognize that digitalization and some of the business models that it facilitates present important challenges for international taxation. The report also acknowledged that it would difficult if not possible to ringfence. The digital economy from the rest economy for tax purposes because of the increasingly pervasive nature of the digitalization (OECD, 2015). The 2015 Action 1 report identified a number of key features of digitalization that are potentially relevant from tax perspective. There was recognition that digitalization has also accelerated and changed the spread of global value chains in which MNEs integrate their world operations. More specially, the report observed new phenomena such as the collection and exploitation of data, network effects and the emergence of new business models. Multi-sided platforms, as exacerbating the challenges to the existing tax rules. 
It was stated that digitalization presents no unique BEPS issues, but that some digital business models can exacerbate BEPS concerns. As such, there was a clear expectation that the consistent and widespread implementation of the BEPS package would substantially address many of the double non-taxation concerns raised by digitalization (Adigbole and Olaoye, 2013). In addition to BEPS issues, the 2015 Action 1 report also identified a number of boarder tax challenges raised by digitalization, notably in relation to connection, data and characterization. These challenges were acknowledged as going beyond BEPS and were also recognized as relating to the question of how taking rights on income generated from cross-border activities in the digital age should be allocated among countries.

In the area of indirect taxation, the 2015 Action 1 report recognized that new challenge arose in particular with respect to the collection of value-added tax/goods and services tax (VAT/GST) on the continuously growing volumes of goods and services that are purchased online by private consumers from foreign suppliers. To address these indirect tax concerns, it was recommended that countries should implement the OECDs international VAT/GST guidelines (OECD, 2017), and in particular the destination principle for determining the place of taxation of cross-border supplies, and consider implementing the mechanisms for the effective collection of VAT/GST presented in the Guidelines (Adewoye et al, 2013). The 2015 Action 1 Report also identified a number of possible approaches for a more effective VAT/GST collection on the significantly growing volume of import of low value goods from online sales

To tackle the broader direct tax issues raised by digitalization, it was concluded that countries could introduce whatever rules or options that work for them, provided they respected their existing international obligations, including those set out in their tax treaties. Further, it was recognized that the measures developed in the BEPS project would mitigate some aspects of the broader tax challenges and that the implementation of the measures to address the VAT/GST challenges would lead to a more effective and efficient collection of these taxes in the market jurisdiction.

\subsubsection{Challenges of Taxing Digital Economy in Nigeria}

The applicable rules for corporate taxation in Nigeria do not effectively capture the realities of a modern economy in our world of fast-paced digital transactions (Oseni, 2015). Given that non-resident companies are taxed in Nigeria based on profits derived from Nigeria, the question as to whether a foreign company is liable to income tax in Nigeria is usually controversial (Etim, Jeremiah and Jeremiah, 2019). Section 13 of Companies Income Tax Act (CITA) implies that a non-resident company must have physically performed activities in Nigeria, directly or indirectly, before such a company can be liable to income tax in Nigeria (Otienoet al, 2013). Thus, where a software company provides online data to users in Nigeria without being physically presence in Nigeria in any form, it may be difficult to conclude that such a company is liable to seen CIT in Nigeria although the company could have derived income from Nigeria. A major challenge is therefore determining at what point such nonresident would be deemed to have carried on business in Nigeria and thus liable to income tax in Nigeria (Wasao, 2014). This is because the absence of the required fixed based or physical operation in Nigeria under Section 13 of CITA as made it difficult for the FIRS to establish liability of such foreign companies to Nigerian tax.

To ensure that digital companies do not escape tax in Nigeria, the FIRS has often required Nigerian companies to withhold tax on all payment made to non-resident person regardless of the non-establishment of the tax presence specified under Section 13 of CITA (Saad, 2013). This requirement has encountered resistance from payers given that such non-resident persons may not be liable to tax under Nigerian laws. However, the FIRS seem to have succeeded in ensuring that VAT is deducted and accounted for on cross border payments for transaction between foreign companies and Nigerian companies. Thus, the absence of relevant provisions in the Nigeria tax laws covering taxation of digital activities is a major challenge that has resulted in loss of revenue to the government of Nigeria (Beeson, Soondram and Jugurnath, 2016).

Another problem is the use of electronic tax systemin tax administration. One of the challenges of electronic taxation in Nigeria is that only the FIRS, which is the tax authority at the federal level, has fully automated its processes. Many tax authorities at the state level are still using manual tax processes, except for a few states such as Lagos State and Akwalbom State lately which has introduced e-filing, e-tax payments and e-tax clearance certificate systems (Dzidonu, 2012). This situation inhibits effective collaboration between tax authorities at the federal and state levels to prevent double taxation (Adimassu and Jerene,2015). There is a need for state revenue authorities to automate their processes to provide the necessary synergy with the FIRS. The level of Tax Identification Number compliance in the states is not encouraging. The benefit of this is that it would contribute positively to the rating of Nigeria on the ease of doing business index as investors would find it easy to fulfil their tax obligations to the federal and state governments through convenient and transparent electronic tax payment platforms (Harrison and Nahashon, 2015). It would also assist tax authorities to easily share information on a taxpayer and build up a comprehensive tax history of a taxpayer and as well as capturing digital transactions into tax net (Marandu, Mbekomize and Ifezue, 2014). 


\subsection{Theoretical Review}

The agency theory is concerned with the relationship between the principal and the agent of the principal. This advocates that the firm can be viewed as a connection of between resource holders. An agency relationship arises whenever one or more individual, called principals, hire one or more other individuals, called agents, to perform some service and then delegate decision-making authority to such agents. The agency theory concept was initially advanced by Berle and Means (1932), who argued that due to a continuous dilution of equity ownership of large corporations, ownership and control become more separated.

In accordance with the agency theory, governments (executive, judicial and legislature), irrespective of the level, are representatives of the people. They are seen as agents of the citizenry or tax payers, who in turn are their principal. They are by law and as a matter of social responsibility, accountable to the people (Jeremiah, 2018). They are expected to render stewardship reports in the form of timely, relevant, detailed and reliable financial reports to the people who have either elected or appointed them to represent their interests. Aside the people, benefactor agencies also see the government or their agencies as their agents. They owe them financial reports, detailing the how the amounts given to them were utilized. This theory is related to present study because of the fact that the study has to do with adequate revenue generation to government through taxation of digital transactions. Thus, the theory is adopted in this study.

\subsection{Empirical Review}

Saad (2014) examined tax knowledge, complexity and compliance based on taxpayers' view so as to uncover the reasons for non-compliance. A survey research design was used to obtain data for analysis with the aid of thematic statistical techniques. The result revealed that tax payers have inadequate technical knowledge and perceive tax system as complex and therefore contributing to non-compliance behaviour of tax payers.

Beeson et al, (2016) assessed the determinants of income tax compliance in Mauritius for individual tax payers. The study adopted primary survey design to obtain data which was analyzed with the aid of thematic statistical analysis. Their study result suggests that tax knowledge impact significantly on tax compliance and that statutory audit, penalties personal financial constraints perceptions of government expenditure influences compliance level. The study concluded that reduction of non-compliance should be some collaborative efforts between tax payers and tax administrative.

Maranduet al, (2014) examined the determinants of tax compliance from social marketing point of view. The study obtained data from 18 empirical studies published between 1985 and 2012 from across the globe, the study found lack of theoretical framework to help guide the selection of determinants of tax compliance from several researchers. The study suggested the development and use of theory-based set of relevant determinants of tax compliance and tax policy makers should desist from the use of conventional coercive methods used to compel tax compliance.

Palil and Mustapha (2011) evaluated the determinants of tax compliance in Malaysia. The study used survey method to obtained data for analysis. The result suggested that tax compliance is strongly influenced by tax payer's tax knowledge which varies significantly among respondents. It further revealed the probability of being audited, perception of government spending, penalties, personal financial constraints, and the influence of referent groups as determinants of tax compliance in Malaysia.

In all the studies reviewed and to the best of the researchers' knowledge, none of them examinestaxation in a digitalized Nigerian economy with focus on the challenge of compliance. Hence, the need for the present study.

\section{Methodology}

The researchers adopted a survey research design with questionnaire used to collect the necessary data. Moreover, a cross-section data were obtained. Data were sourced from the Federal InlandRevenue Service (FIRS). The population of the study was the total number of workers, which is forty (40) FIRS in AkwaIbom state. The security officers and those that do not have idea of the subject matter were excluded. The questionnaire was structured using the five-point Likert scale rated as follows: Strongly Agreed (SA) = 5;Agreed (A) =4; Disagreed (D)=3; Strongly Disagreed $(\mathrm{SD})=2$; Undecided $(\mathrm{U})=1$. The data wereanalyzed using SPSS version 25 .

The simple percentage, descriptive statistics, and simple linear regression were used to analyze the data and to test the hypotheses. The level of significance considered was 5\%. Cronbach's Alpha Statistics was also used to test the reliability of the data collected for the study. The model for the study is stated as:

$\mathrm{TC}=\beta_{\mathrm{o}}+\beta_{1} \mathrm{DE}+\mathrm{e}_{\mathrm{t}}$,

Where:

$\mathrm{TC}=$ Tax Compliance;

$\mathrm{DE}=$ Digitalization of Economy (DE); 
$\beta_{0}=$ Intercept of TC;

$\beta_{1}=$ Coefficient of $\mathrm{DE}$, and

$\mathrm{e}_{\mathrm{t}}=$ Random error term.

\subsection{Data analysis and discussion}

In this section of the study, the researchers are concerned with data presentation, analysis and the discussion of findings.

\subsection{Data Presentation}

The data collected for the study were presented below:

Table 4.1: Digitalization of Economy and Tax Compliance in Nigeria.

\begin{tabular}{|c|c|c|c|c|c|c|}
\hline $\mathbf{S} / \mathbf{N}$ & Question & $\mathbf{S A}$ & $\mathbf{A}$ & D & SD & $\mathbf{U}$ \\
\hline \multirow[t]{2}{*}{1.} & \multirow[t]{2}{*}{ Digital transactions are coming up in the economy of Nigeria. } & 30 & 10 & 0 & 0 & 0 \\
\hline & & $75 \%$ & $25 \%$ & $0 \%$ & $0 \%$ & $0 \%$ \\
\hline \multirow[t]{2}{*}{2.} & \multirow{2}{*}{$\begin{array}{l}\text { Digital transactions are possible because of the level of } \\
\text { technological improvement in the world. }\end{array}$} & 20 & 16 & 0 & 0 & 4 \\
\hline & & $50 \%$ & $40 \%$ & 0 & 0 & $10 \%$ \\
\hline \multirow[t]{2}{*}{3.} & \multirow{2}{*}{$\begin{array}{l}\text { Digitalization of the economy of Nigeria pave way for digital } \\
\text { transactions to exist in the economy. }\end{array}$} & 20 & 16 & 0 & 2 & 2 \\
\hline & & $50 \%$ & $40 \%$ & $0 \%$ & $5 \%$ & $5 \%$ \\
\hline \multirow[t]{2}{*}{4.} & \multirow[t]{2}{*}{ Digitalization of economy of Nigeria has tax implications. } & 24 & 12 & 2 & 2 & 0 \\
\hline & & $60 \%$ & $30 \%$ & $5 \%$ & $5 \%$ & $0 \%$ \\
\hline \multirow[t]{2}{*}{5.} & \multirow{2}{*}{$\begin{array}{l}\text { The compliance habits in payments of taxes by companies } \\
\text { that carry on e-transactionsis low. }\end{array}$} & 28 & 12 & 0 & 0 & 0 \\
\hline & & $70 \%$ & $30 \%$ & $0 \%$ & $0 \%$ & $0 \%$ \\
\hline \multirow[t]{2}{*}{6.} & \multirow{2}{*}{$\begin{array}{l}\text { Negative compliance in payments of taxes affect the tax } \\
\text { revenue yield of the economy of Nigeria. }\end{array}$} & 24 & 16 & 0 & 0 & 0 \\
\hline & & $60 \%$ & $40 \%$ & $0 \%$ & $0 \%$ & $0 \%$ \\
\hline
\end{tabular}

Source: Field Survey, 2020

From Table 4.1 above, digital transactions are coming up in the economy of Nigeria; digital transactions are possible because of the level of technological improvement in the world; digitalization of the economy of Nigeria pave way for digital transactions to exist in the economy; digitalization of economy of Nigeria has tax implications; the compliance habits in payments of taxes by companies that carry on e-transactions is low and negative compliance in payments of taxes affect the tax revenue yield of the economy of Nigeria. This was owing to the fact that the number of respondents that chose Strongly Agreed (SA) and Agreed (A) in each of the questions greater than the numbers of respondents that chose Disagreed (D) and Strongly Disagreed (SD).

\subsection{Data Analysis}

4.2.1 Reliability Test

The Cronbach's Alpha Statistics computed was presented on the table below:

Table 4.2: Reliability Statistics

\begin{tabular}{|c|c|c|c|c|c|c|}
\hline $\mathbf{S} / \mathbf{N}$ & Questions & $\begin{array}{l}\text { Scale Mean if } \\
\text { Item Deleted }\end{array}$ & $\begin{array}{l}\text { Scale } \\
\text { Variance if } \\
\text { Item Deleted }\end{array}$ & $\begin{array}{l}\text { Corrected } \\
\text { Item-Total } \\
\text { Correlation }\end{array}$ & $\begin{array}{l}\text { Squared } \\
\text { Multiple } \\
\text { Correlation }\end{array}$ & $\begin{array}{l}\text { Cronbach's } \\
\text { Alpha if Item } \\
\text { Deleted }\end{array}$ \\
\hline 1. & $\begin{array}{l}\text { Digital transactions are } \\
\text { coming up in the economy } \\
\text { of Nigeria. }\end{array}$ & 22.2000 & 14.010 & 0.781 & 0.800 & 0.926 \\
\hline 2. & $\begin{array}{l}\text { Digital transactions are } \\
\text { possible because of the } \\
\text { level of technological } \\
\text { improvement in the world. }\end{array}$ & 22.7500 & 8.910 & 0.916 & 0.975 & 0.909 \\
\hline 3. & $\begin{array}{l}\text { Digitalization of the } \\
\text { economy of Nigeria paves } \\
\text { way for digital transactions } \\
\text { to exist in the economy. }\end{array}$ & 22.7000 & 9.549 & 0.935 & 0.983 & 0.895 \\
\hline 4. & $\begin{array}{l}\text { Digitalization of economy } \\
\text { of Nigeria has tax } \\
\text { implications. }\end{array}$ & 22.5000 & 10.923 & 0.962 & 0.954 & 0.888 \\
\hline
\end{tabular}




\begin{tabular}{llcccc}
\hline 5. $\begin{array}{l}\text { The compliance habits in } \\
\text { payments of taxes by } \\
\text { companies that carry on e- } \\
\text { transactions is low. }\end{array}$ & 22.2500 & 13.833 & 0.787 & 0.841 & 0.924 \\
6. $\begin{array}{l}\text { Negative compliance in } \\
\text { payments of taxes affect } \\
\text { the tax revenue yield of the } \\
\text { economy of Nigeria. }\end{array}$ & 22.3500 & 13.669 & 0.777 & 0.824 & 0.922 \\
\hline
\end{tabular}

Source: Researchers' Computation, 2020

From the table 4.2 above, each of the data for each question collected was reliable owing to the fact that the statistics were all significant (greater than $60 \%$ ).

\subsubsection{Descriptive Statistics}

The descriptive statistics was computed and presented on the table as shown on the Table 4.3 below:

Table 4.3: Descriptive Statistics

\begin{tabular}{|c|c|c|c|c|c|c|}
\hline $\mathrm{S} / \mathbf{N}$ & Question & $\mathbf{N}$ & MIN & MAX & MEAN & STD \\
\hline 1. & $\begin{array}{l}\text { Digital transactions are coming up in } \\
\text { the economy of Nigeria. }\end{array}$ & 40 & 4.00 & 5.00 & 4.7500 & 0.43853 \\
\hline 2. & $\begin{array}{l}\text { Digital transactions are possible } \\
\text { because of the level of technological } \\
\text { improvement in the world. }\end{array}$ & 40 & 1.00 & 5.00 & 4.2000 & 1.18105 \\
\hline 3. & $\begin{array}{l}\text { Digitalization of the economy of } \\
\text { Nigeria pave way for digital } \\
\text { transactions to exist in the economy. }\end{array}$ & 40 & 1.00 & 5.00 & 4.2500 & 1.05612 \\
\hline 4. & $\begin{array}{l}\text { Digitalization of economy of Nigeria } \\
\text { has tax implications. }\end{array}$ & 40 & 2.00 & 5.00 & 4.4500 & 0.81492 \\
\hline 5. & $\begin{array}{l}\text { The compliance habits in payments of } \\
\text { taxes by companies that carry on e- } \\
\text { transactions is low. }\end{array}$ & 40 & 4.00 & 5.00 & 4.7000 & 0.46410 \\
\hline 6. & $\begin{array}{l}\text { Negative compliance in payments of } \\
\text { taxes affect the tax revenue yield of } \\
\text { the economy of Nigeria. }\end{array}$ & 40 & 4.00 & 5.00 & 4.6000 & 0.49614 \\
\hline
\end{tabular}

Source: Researchers' Computation,2020

The table above showed the number of respondents, minimum, maximum, mean and standard deviation of responses. In each of the question, deviation from the mean was not high.

\subsubsection{Regression Analysis}

The simple linear regression was computed and presented on the Table 4.4 below:

\section{Table 4.4: Summary of Analysis}

\begin{tabular}{lllllll}
\hline Variable & Beta $(\boldsymbol{\beta})$ & P-Value & Remark & DW & $\mathbf{R}^{2}$ & Adjusted-R $^{2}$ \\
\hline DE & -0.532 & 0.000 & Significant & 2.354 & 0.707 & 0.704 \\
\hline Source:Researchers ${ }^{\prime}$ Computation, 2020 & & & & &
\end{tabular}

Source:Researchers'Computation,2020

\section{Dependent Variable: TC}

From the table above, digitalized economy (DE)wields a negative but significant effect on Tax Compliance (TE) in Nigerian Economy (p-value < 0.05). This indicates that a percentage increase in DE resulted in $53.2 \%$ decrease in TC. The DW statistics of 2.354 indicated that there was no first order autocorrelation in the model. $\mathrm{R}^{2}$, which is the coefficient of determination, showed that $70.7 \%$ changes in TC was caused by the influence of DE.

\subsection{Discussion of the Findings}

The analysis indicates that digitalization of the economy of Nigeria had a negative implication on the tax compliance in Nigeria. Tax revenue is one of the sources of income to Federal government in Nigeria. 
In this case, digital transactions do not affect the economy of Nigeria positively through payment of taxes to the government of Nigeria. In the economy of Nigeria, digital transactions known as e-transactions are growing at higher rate and the expectation is that it should affect the economy positively. One of the major challenges is that taxation of e-transactions is not part and parcel of the tax laws in Nigeria. This is why huge amount of tax revenue isevaded. Digitalization of the economy of Nigeria pave way for digital transactions to exist in the economy. Technological changes are felt in every economy in the world today. New ideas of doing things are used. Digital transactions in Nigeria came as a result of technological changes experienced in the economy of Nigeria. If the economy of Nigeria continues this way, the country as a whole will not feel the impact of digitalization of the economy. This is why tax payers must be educated well in respect of e-transactions (Palil and Mustapha, 2011).

\section{Conclusion and Recommendations}

The study was conducted to examine the effect of digitalization of economy on tax compliance in Nigeria. The simple percentage, descriptive statistics, simple linear regression and correlation were used to analyse the data. From the findings, the researchers concluded that digitalization of economy had negative effect on tax compliance in Nigeria as a result of issues surrounding its introduction and application. It is therefore recommended that the government of Nigeria should consider developing tax policy that would aid taxing e-transactions, tax education and including taxation of e-transactions in the tax laws. By so doing the digital transactions would fully impact the economy of Nigeria positively.

\section{References}

Adewoye, J. O., and Olaoye, C. O. (2014).Usage of information technology to enhance professional Productivity among accountants in Ekiti State.International Journal of Accounting and Financial Management Research,4(2): 7-18.

Adewoye, J. O., Ademola, A. O., Afolabi O. D., and Oyeleye, O. (2013). Performance impact of information and communication technology (ICTs) on women entrepreneurs in South Western Nigeria.

Adigbole, E. A., and Olaoye, C. O. (2013).The application of information technology on administrative efficiency in Nigeria Universities. A case study of five selected Universities in Ekiti state, Research Journal of management, 1(1): 12-20.

Adimassu, N. A., and Jerene, W. (2015). Determinants of voluntary tax compliance behaviour in self-assessment system: Endemic from SNNPRS, Ethiopia. International Journal of Science Research:2319-7064.

Akintoye, I. R., and Tashie, G. A. (2013). The effect of tax compliance on economic growth and development in Nigeria, West Africa Approach: BritishJournal of Accounting, Finance and Social Sciences, 11.

Amabali, A. R. (2009). E-Government Policy: Ground issues in e-filing system, European Journal of Social Sciences,21(13): 189-45.

Appah, E., and Ogbonna, G. N. (2014).Self-Assessment Scheme and Revenue Generation in Nigeria. Developing Countries Studies, 4(19): 62-98.

Batrancea, L., Nichita, R. and Batrancea, I. (2012).Understanding the determents of Tax Compliance behaviour as a prerequisite for increasing public levies in Romania. The USV annals of economic and public administration, 12(15): 16-22.

Bassey, O.U. (2016). Personal Income Tax in Nigeria, (Second Edition) Lagos: The CIBN Press Ltd

Beeson, D., Soondram, H. P., and Jugurnath, B. (2016).Assessing the determinants of income tax compliance Mauritius: A study of individual taxpayers. University of Mauritius

Devos, K. (2014). Factors influencing individual taxpayers compliance behaviour:Springer publisher.

Dzidonu, C.K. (2012).Using Information and Communication Technology (ICT) in Managing National Resources.Paper Presented at the $7^{\text {th }}$ Internal Audit Forum, Accra.

Efunboade, A. O. (2014). Impact of ICT on Tax Administration in Nigeria.Computer Engineering and Intelligent Systems, 5(8): 26-29.

Etim, R.S., Jeremiah, M.S. and Jeremiah, O.O., (2019). Attracting Foreign Direct Investment (FDI) In Nigeria through Effective Tax Policy Incentives. International Journal of Applied Economics, Finance and Accounting, 4(2), pp.36-44.

Ernst, E., and Young, K. (2018).Growth and employment project (GEM): Digital economy industry value chain, Nigeria.

Harrison, M. M.,andNahashon, K. (2015). Effects of online tax system on tax compliance among small taxpayers in Meru County, Kenya.International Journal of Economics, Commerce and Management, 3(12): 280.

Ibrahim, O., Jeremiah, M. S., \&Ithnin, N. (2008).The framework for intangible information assets evaluation for adequate managerial control systems.JurnalTeknologiMaklumat. Vol. 20, No.2

Jeremiah, M. S. (2018). Corporate Social Responsibility Contribution to Environmental Sustainability in Developing Countries: The Accountability Perspective. International Journal of Business and Management, 13(1). 
Marandu, E. E., Mbekomize, C. and Ifezue, A. (2014). Determinants of tax compliance: a review of factors and conceptualizations. University of Botswana, Botswana

Okello, A. (2014).Managing income tax compliance through self-assessment" IMF working paper No. 14/41.

Oseni, M. (2015). Sustenance of tax administration by information and communications technology in Nigeria, Archieves of Business Research, 4(1): 47-54.

Otieno, O.C., Oginda, M., Obura, J. M., Aila, F. O., OjeraandSiringi, E. M. (2013). Effect of information systems on revenue collection by local authorities in Homa Bay County, Kenya, Universal Journal of Accounting and Finance, 1(1): 29-33.

Palil, M. R. and Mustapha, A. F. (2011). Determinants of tax compliance in Asia: a case study of Malaysia: The National University of Malaysia

Saad, N. (2013). Tax knowledge, tax complexity and tax compliance-taxpayers view. Procedia-Social and behavioural sciences, 109:1069-1075

Wasao, D. (2014).The effect of online tax system on tax compliance among small taxpayers.University of Nairobi. 